\title{
Erratum to: Editorial introduction: urban management in developing economies: challenges for public policy
}

\author{
Amit Basole $\cdot$ Rajesh Bhattacharya
}

Published online: 28 July 2017

(C) Indian Institute of Management Calcutta 2017

\section{Erratum to: Decision (June 2017) 44(2):85-89 DOI 10.1007/s40622-017-0158-4}

In the original publication, the article title was incorrectly published as "Editorial introduction: urban management in developing economics: challenges for public policy". The correct title should read as "Editorial introduction: urban management in developing economies: challenges for public policy".

The online version of the original article can be found under doi:10.1007/s40622-017-0158-4.

\footnotetext{
A. Basole

Azim Premji University, Bengaluru, India

e-mail: amit.basole@apu.edu.in

R. Bhattacharya $(\square)$

Indian Institute of Management Calcutta, Kolkata, India

e-mail: rb@iimcal.ac.in
} 